\title{
54. PETROGENESIS OF MID-ATLANTIC RIDGE BASALTS AT DSDP LEG 37 HOLES 332A AND 332B FROM MAJOR AND TRACE ELEMENT GEOCHEMISTRY
}

\author{
A.E. Bence' and S.R. Taylor, Research School of Earth Sciences, \\ Australian National University, Canberra, Australia
}

\begin{abstract}
Major and trace element studies of five fresh basalts from DSDP Leg 37, Holes 332A and 332B, adjacent to the crest of the MidAtlantic Ridge, reveal that four of the samples can be related to derivation by varying degrees of partial melting, from a homogeneous source region. The fifth sample is derived from a distinct source region. The chemistry of the samples cannot be derived by fractional crystallization from a common parental magma. The trace element abundance levels in the source regions lie within a range of 1-2 times those of chondrites, and there is no light REE depletion. Thus the source regions appear to be undepleted. Four of the samples experienced severe fractionation of ferromagnesian elements before eruption, and one sample contains $30 \%$ cumulate plagioclase.
\end{abstract}

\section{INTRODUCTION}

Major and selected trace element abundances have been determined for five basaltic rocks recovered on Leg 37 at Holes 332A and 332B adjacent to the crest of the Mid-Atlantic Ridge. The objectives of this study have been to determine the chemistry and mineralogy of the upper mantle source regions of these basalts, characterize the chemistry of the parental liquid(s) and the conditions of magma genesis, and the subsequent fractionation paths of the derivative liquids. Ultimately we wish to use our findings to constrain possible models of oceanic crust formation of an actively spreading rift.

Four of the five samples studied are basalts, whereas the fifth is a gabbro. These represent the freshest samples made available to us for this preliminary report. One of the samples (332A-34-2, 6-9 cm) is from the second drilling attempt at Site 332 . The remainder are from the third penetration (Hole 332B) made a short distance away. Preliminary mineralogical studies have been conducted on these samples by Hodges and Papike (this volume).

\section{MAJOR ELEMENT CHEMISTRY}

Major element abundances were obtained for the five samples by fusion of a split of each sample on an iridium strip heater and subsequent analysis of the glass beads by electron microprobe. The details of the technique are described by Nicholls (1974). The analyses obtained in this manner are reported in Table 1 and in

'Permanent address: Dept. of Earth and Space Sciences, State University of New York, Stony Brook, N.Y.
Chapter 2 (this volume). USGS standard basalt powders were also fused and interspersed as monitors among the unknowns. Results obtained for one of these standards (BCR-1) are reported in Table 1. Approximate detection limits for the less abundant constituents are: $\mathrm{Na}_{2} \mathrm{O}: 0.15 \% ; \mathrm{K} 2 \mathrm{O}: 0.05 \% ; \mathrm{TiO}_{2}: 0.07 \%$; $\mathrm{Cr}_{2} \mathrm{O}_{3}$ : $0.08 \%$; and $\mathrm{MnO}: 0.08 \%$. Total iron as "FeO" and $\mathrm{FeO}$ and $\mathrm{Fe}_{2} \mathrm{O}_{3}$ were obtained on splits of three of the samples.

The five samples from Holes $332 \mathrm{~A}$ and $332 \mathrm{~B}$ studied for this report show extreme major element differences between them with the most pronounced differences occurring for " $\mathrm{FeO}$," $\mathrm{MgO}$, and $\mathrm{Al}_{2} \mathrm{O}_{3}$. Titania also varies significantly between the samples. All of the samples are subalkaline and, on the basis of normative mineralogy, are tholeiitic (Figure 1). However they range from olivine tholeiite (332B-21-1, 27-30 cm) with $27 \%$ normative olivine to quartz. Normative hypersthene varies from about $11 \%$ to $18 \%$.

Values of $\mathrm{Mg} /\left(\mathrm{Mg}+\mathrm{Fe}^{2+}\right.$ ) (for iron recalculated to $\mathrm{Fe}^{3+} /\left[\mathrm{Fe}^{2+}+\mathrm{Fe}^{3+}\right]=0.1$ ) range from 0.785 to 0.613 . Ratios less than about $0.69-0.71$ are thought to be a consequence of the fractionation of ferromagnesian phases from the parental liquids in the upper mantle assuming mantle olivine has the composition of $\sim$ Fo89 and the liquids were derived by partial melting not exceeding about 20\% (Green et al., 1974). On that basis, Samples 332A-34-2, 6-9 cm) and 332B-22-4, 18-20 cm have experienced significant fractionation involving ferromagnesian phases and 332B-19-1, 107-110 cm is relatively unfractionated. Sample 332B-2-5, 109-111 $\mathrm{cm}$, the coarse-grained specimen, although apparently unfractionated with respect to ferromagnesian phases, contains approximately $30 \%$ plagioclase phenocrysts 
TABLE 1

Major and Trace Element Data and CIPW Norms of Basalts. (Major Element Data in wt \%; (Trace element data in ppm (wt)

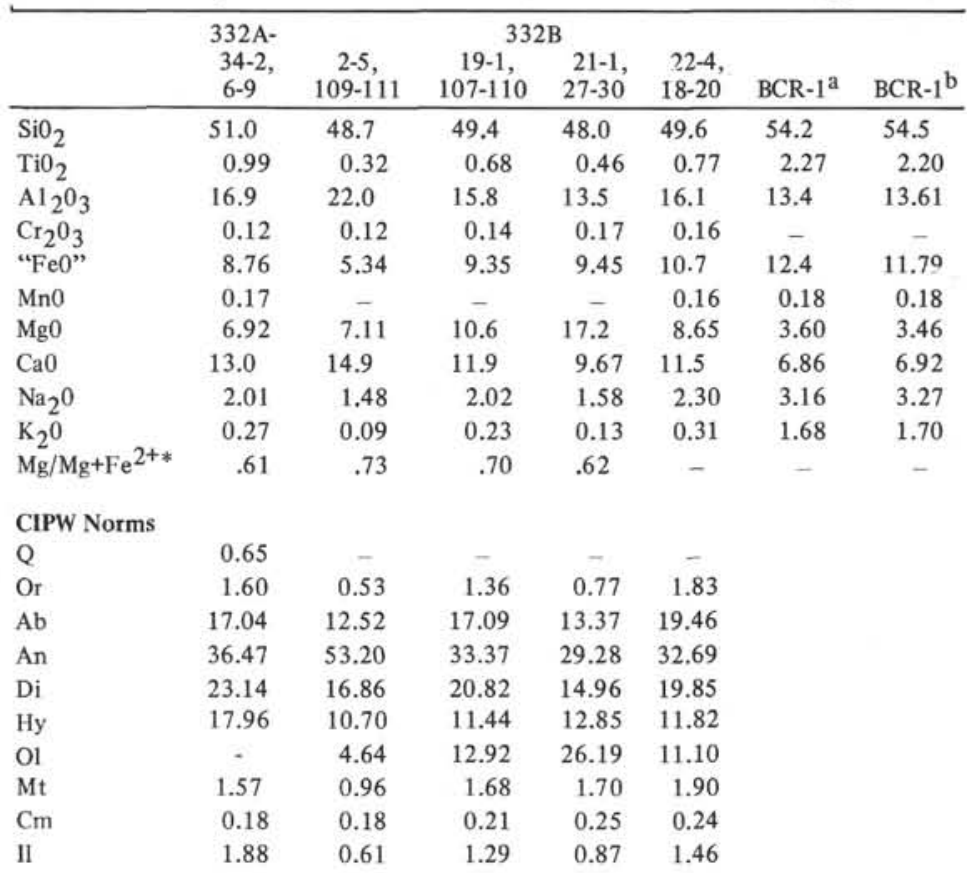

Independent Chemical Iron (E. Kiss ana'yst)

$\begin{array}{lllllr}\mathrm{Fe} 0 & 5.93 & 3.84 & - & - & 7.09 \\ \mathrm{Fe}_{2} \mathrm{O}_{3} & 2.58 & 1.28 & - & - & 3.38 \\ \text { "Fe0" } & 8.25 & 4.99 & & - & 10.13\end{array}$

Large Cations

$\begin{array}{lllllllll}\mathrm{Ba} & 36 & 7.4 & 19 & 7.8 & 16 & 672 & 661 & 580-713 \\ \mathrm{~Pb} & 0.56 & 0.32 & 0.19 & 0.24 & 0.10 & 15.7 & 13.4 & -\end{array}$

Large high valency cations

$\begin{array}{lcccccccc}\text { Th } & 0.49 & 0.09 & 0.29 & 0.18 & 0.26 & 5.53 & 5.67 & 4.98-6.02 \\ \mathrm{U} & 0.16 & - & 0.11 & - & - & 1.64 & 1.74 & 1.68-1.8 \\ \mathrm{Zr} & 56 & 17 & 38 & 18 & 36 & 175 & 185 & - \\ \mathrm{Hf} & 1.4 & 0.6 & 0.9 & 0.7 & 1.0 & 5.01 & 4.8 & 4.57-5.23 \\ \mathrm{Nb} & 8.6 & 1.8 & 5.4 & 2.9 & 4.1 & 12.7 & 13 & - \\ \mathrm{Sn} & 0.52 & 0.21 & 0.42 & 0.24 & 0.38 & 2.32 & - & - \\ \mathrm{Mo} & 0.51 & - & 0.48 & 0.36 & 0.38 & - & - & -\end{array}$

Rare earth elements

\begin{tabular}{lclllllll}
$\mathrm{La}$ & 5.0 & 1.3 & 3.5 & 1.6 & 2.6 & 25.2 & 24.9 & $23.7-26.2$ \\
$\mathrm{Ce}$ & 13 & 3.2 & 8.0 & 4.1 & 6.6 & 52.6 & 53.6 & $51.3-54.9$ \\
$\mathrm{Pr}$ & 1.7 & 0.46 & 1.16 & 0.58 & 0.91 & 6.54 & 7 & - \\
$\mathrm{Nd}$ & 7.5 & 2.1 & 5.2 & 2.7 & 4.2 & 23.7 & 30.05 & $28.5-32.1$ \\
$\mathrm{Sm}$ & 2.2 & 0.73 & 1.65 & 1.0 & 0.39 & 6.00 & 6.90 & $6.52-7.44$ \\
$\mathrm{Eu}$ & 0.74 & 0.32 & 0.63 & 0.40 & 0.59 & 1.88 & 1.95 & $1.87-1.98$ \\
$\mathrm{Gd}$ & 2.8 & 1.1 & 2.3 & 1.5 & 1.8 & 6.45 & 7.16 & $6.45-8.02$ \\
$\mathrm{~Tb}$ & 0.51 & 0.22 & 0.43 & 0.28 & 0.36 & 0.99 & 1.07 & $0.96-1.15$ \\
$\mathrm{Dy}$ & 3.2 & 1.4 & 2.7 & 1.9 & 2.4 & 6.20 & 6.19 & $5.65-6.55$ \\
$\mathrm{Ho}$ & 0.79 & 0.32 & 0.68 & 0.47 & 0.64 & 1.29 & 1.22 & $1.15-1.46$ \\
$\mathrm{Er}$ & 2.3 & 0.99 & 1.9 & 1.4 & 1.8 & 3.70 & 3.77 & $3.51-4.5$ \\
$\mathrm{Tm}$ & 0.33 & 0.15 & 0.29 & 0.21 & 0.28 & 0.61 & 0.5 & - \\
$\mathrm{Yb}$ & 2.0 & 0.9 & 1.7 & 1.3 & 1.6 & 3.66 & 3.49 & $3.21-3.74$ \\
$\mathrm{Lu}$ & 0.31 & 0.14 & 0.27 & 0.19 & 0.26 & 0.57 & 0.56 & $0.53-0.63$ \\
$\mathrm{EREE}$ & 42 & 13.4 & 30.5 & 17.6 & 26 & - & - & - \\
$\mathrm{Y}$ & 20 & 10 & 20.5 & 12 & 18 & 29.8 & 40 & - \\
$\mathrm{La} / \mathrm{Yb}$ & 2.51 & 1.60 & 2.0 & 1.27 & 1.58 & & & \\
$\mathrm{La} / \mathrm{Sm}$ & 2.27 & 1.78 & 2.12 & 1.6 & 1.87 & & & \\
\hline
\end{tabular}

${ }^{a}$ USGS standard basalt BCR-1 volatile corrected microprobe (ANU) analysis of fused glass (no flux). ${ }^{b}$ USGS BCR-1 recommended values.

${ }^{c}$ ANU data, spark source mass Spec, Precision $(< \pm 5 \%)$.

d Range of values from: Arth and Hanson (1975); Brunfelt and Heier (1971); Frey et al., (1974); Gast, et al., (1970); Goles et al., (1971; Haskin (1970); Philpotts and Schnetzler (1970).

${ }^{\mathrm{e}}$ Calculated for iron redetermined as $\mathrm{Fe}^{3+} / \mathrm{Fe}^{3+}+\mathrm{Fe}^{2+}=0.1$ 


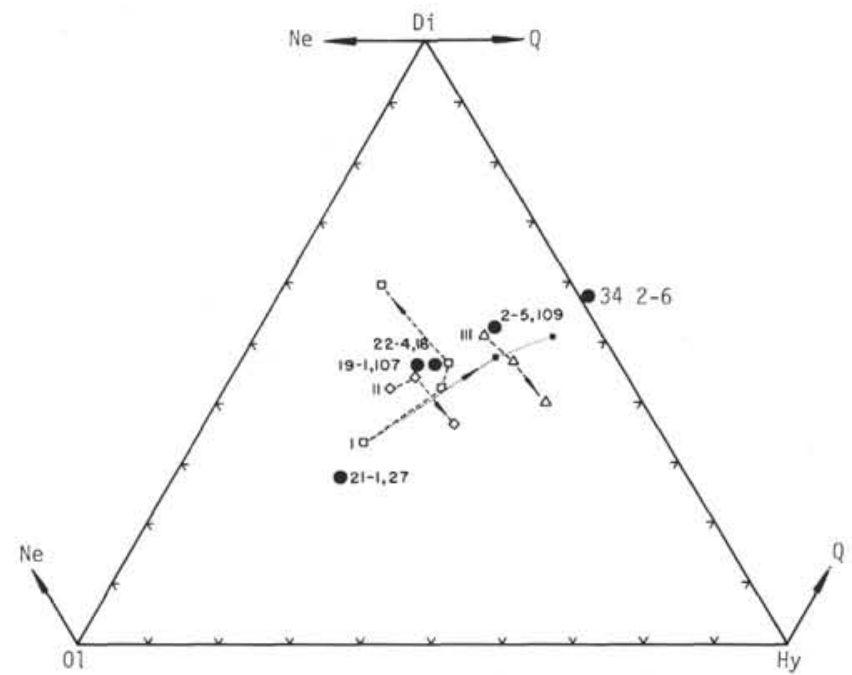

Figure 1. Leg 37 Holes $332 A$ and $332 B$ compositions projected on Di-Ol-Hy ternary. Olivine tholeiite compositions I, II, and III with 0-kbar (dashed) and atmospheric (dotted) fractionation paths from Green et al. (1967) also shown. Note that the Leg 37 samples plot parallel to a low pressure olivine fractionation path. Such a process cannot be used to explain both the major and trace element characteristics of the samples.

(F. Hodges, personal communication) and, in view of the difficulty of producing liquids containing in excess of about $18 \% \mathrm{Al}_{2} \mathrm{O}_{3}$ by partial melting of pyrolitic upper mantle (A.E. Ringwood, personal communication), is almost certainly a plagioclase cumulate.

Sample 334-21-1, 27-30 cm contains xenocrystic aggregates of olivine $\left(\sim \mathrm{Fo}_{90}\right)$. $(\mathrm{F}$. Hodges, personal communication) accounting for its high $\mathrm{Mg} /(\mathrm{Mg}+$ $\mathrm{Fe}^{2+}$ ) ratio (0.785). Assuming that these olivines are truly xenocrysts and not xenoliths, the liquid from which they crystallized would have $\mathrm{Mg} /\left(\mathrm{Mg}+\mathrm{Fe}^{2+}\right) \cong$ 0.7 . If the present rock contains the two components of that assemblage (xenocrysts + host liquid), it contains approximately $40 \%$ xenocrystic and phenocrystic olivine.

$\mathrm{On}$ an $\mathrm{MgO}-\mathrm{Al}_{2} \mathrm{O}_{3}$ variation diagram (Figure 2), selected because of its sensitivity to olivine and plagioclase fractionations, all but one of the samples studied fall along an olivine (Foro) extraction line. Only the coarse-grained plagioclase cumulate 332B-2-5, 109 $111 \mathrm{~cm}$ is not located along this path. Consequently, one is tempted to relate the four samples to a common parent by olivine fractionation. However, as will be shown below, this is not possible.

In addition to their extreme chemical diversity, the basalts studied for this report are unique in another way - they contain some of the lowest titania concentrations observed in basalts recovered by DSDP (Figure 3). From the observed parallel behavior of $\mathrm{Ti}$ and most of the trace elements (see below), we conclude that $\mathrm{Ti}$ behaves as an incompatible element in these basalts, and the wide variations observed in ocean floor basalts, which can be accounted for only in part by fractionation processes, reflect titania heterogeneities in the upper mantle source regions of the basalts.

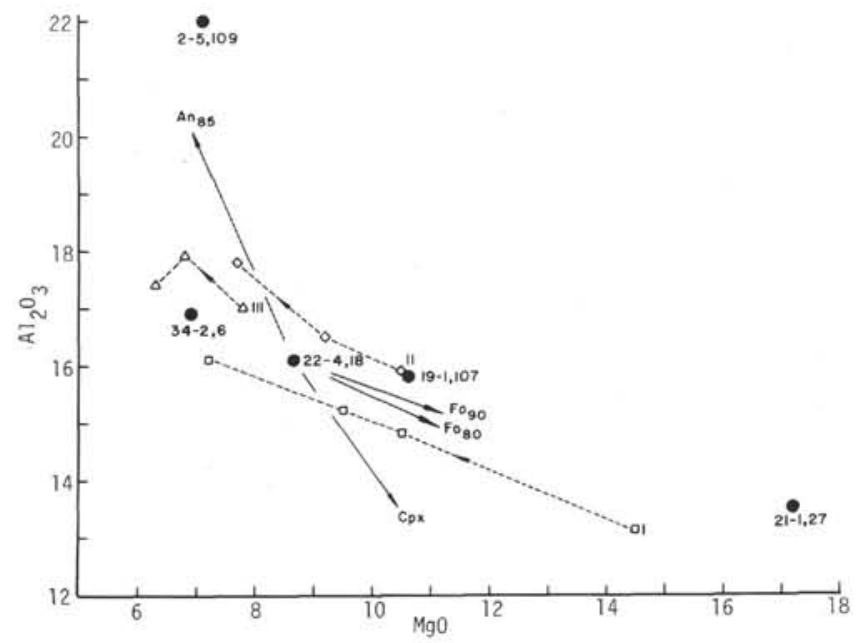

Figure 2. $\mathrm{MgO}-\mathrm{Al}_{2} \mathrm{O}_{3}$ variation diagram for Leg 37 Holes $332 A$ and $332 B$ samples studied. Olivine tholeiite compositions $I, I I$, and III with 9-kbar fractionation paths from Green et al., 1967. Addition lines for plagioclase (An 85), olivine (Fo90-80), and clinopyroxene (Wo 43 En $\left.n_{51} F_{6}\right)$ are shown. See text for discussion.

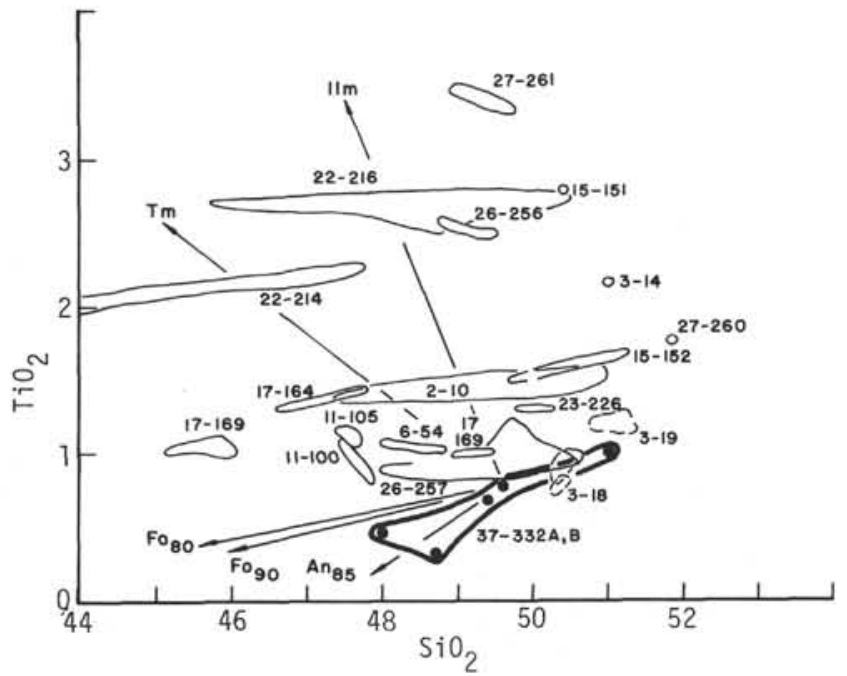

Figure 3. $\mathrm{TiO}_{2}-\mathrm{SiO}_{2}$ variations diagram. Data for other DSDP sites are as follows: 2, 3, Frey et al. (1974); 6, Ridley et al.(1974); 11, Bence (unpublished data); 15, Bence et al. (in press); 17, Bass et al. (1973); 22, Hekinian (1974); 23, Coleman et al. (1973); 26, Kempe (1973); 27, Robinson and Whitford (1974).

\section{TRACE ELEMENTS}

Twenty-four trace elements (Table 1 and Chapter 2, this volume) have been measured by spark source mass spectrometry using the procedures described by Taylor (1965, 1971). A comparison of results obtained for USGS standard basalt BCR-1 with the range of results reported in the literature by other investigators using a variety of techniques is also given. Our data for BCR-1 fall generally within the range of values reported by the other workers, except for Nd, where our values may be systematically low. The precision of our analytical data 
is $\leq \pm 5 \%$, and accuracy, as judged by this interlaboratory comparison with BCR-1 and also with lunar data, is satisfactory.

All the samples have relatively flat REE patterns (Figure 4) with the heavy rare earths (Gd-Lu) varying from $\sim 4$ to 9 times chondritic. In this respect these samples are depleted by factors of 2 to 4 relative to typical mid-ocean ridge basalt (MORB's). However, unlike the large majority of MORB's the light rare earths (La-Sm) are slightly enriched relative to the heavy rare earths. Similar LREE enrichment (but with larger $\mathrm{La} / \mathrm{Yb}$ ratios) has been previously noted in a relatively small number of ocean floor basalts by Kay et al. (1970); Frey et al. (1974); Schilling (1973); Bence et al. (in press) and is typical of oceanic island tholeiites, e.g., Hawaii (Schilling and Winchester, 1969). Interestingly the Site 332 basalts exhibit both LREE and HREE enrichments relative to Sm (Table 1 and Figure 4).

Two of the basalts, both containing cumulate plagioclase, have small positive Eu anomalies, (Eu/Eu* 1.15 and 1.20 , respectively) (Figure 4). The other samples (Figure 4) show no detectable Eu anomaly (Eu/Eu* ranging from 0.97 to 1.06 , within the limits of precision of the data).

The concentrations of $\mathrm{Y}, \mathrm{Ba}, \mathrm{Zr}, \mathrm{Hf}, \mathrm{Nb}$, and $\mathrm{Sn}$ (Table 1) parallel those of the REE (excluding Eu). These elements vary in abundance between samples by a factor of about 4 . These variations are quite consistent and regular (Table 1) in terms of major and other trace element variations between the samples. The five basalts are thus clearly distinguishable on this basis. A similar but not quite so well defined variation is shown by $\mathrm{Pb}$, while the data for $\mathrm{U}$, although incomplete, show the same trend. The Th/U value of 0.25 for Sample 332B-19-1, 107-110 cm is similar to that of other MORB samples. The value of 3.15 obtained for Sample 332A-34-2, 6-9 cm is similar to that for alkali basalts and is consistent with the relatively high abundance levels for the other trace elements and the high $\mathrm{La} / \mathrm{Yb}$ and $\mathrm{La} / \mathrm{Sm}$ ratios in this sample.

\section{DISCUSSION}

Models for the petrogenesis of the DSDP Site 332 basalts must account for the following chemical and mineralogical characters. (1) The diversity of their major element chemistry (especially $\mathrm{FeO}, \mathrm{MgO}, \mathrm{Al}_{2} \mathrm{O}_{3}$ and $\left.\mathrm{TiO}_{2}\right)$; (2) Ratios of $\mathrm{Mg} /\left(\mathrm{Mg}+\mathrm{Fe}^{2+}\right)$; (3) The olivine cumulate character of $332 \mathrm{~B}-21-1,28-30 \mathrm{~cm}$ and the plagioclase cumulate character of 332B-2-5, 109-111 $\mathrm{cm}$. (4) The REE data including: overall depletion of total REE relative to MORB, the generally flat parallel patterns with total abundance levels varying by a factor of 6, and the $\mathrm{La} / \mathrm{Yb}$ and $\mathrm{La} / \mathrm{Sm}$ ratios; (5) The similar and parallel behavior of the REE's, $\mathrm{Pb}, \mathrm{U}, \mathrm{Th}, \mathrm{Y}, \mathrm{Ba}$, $\mathrm{Zr}, \mathrm{Hf}, \mathrm{Nb}$, and $\mathrm{Sn}$.

According to the drilling records, none of the samples studied for this report come definitely from the same cooling unit making it difficult to evaluate postemplacement fractionation effects on the liquids from which they crystallized. However, from major and trace element arguments, it is possible to establish whether or

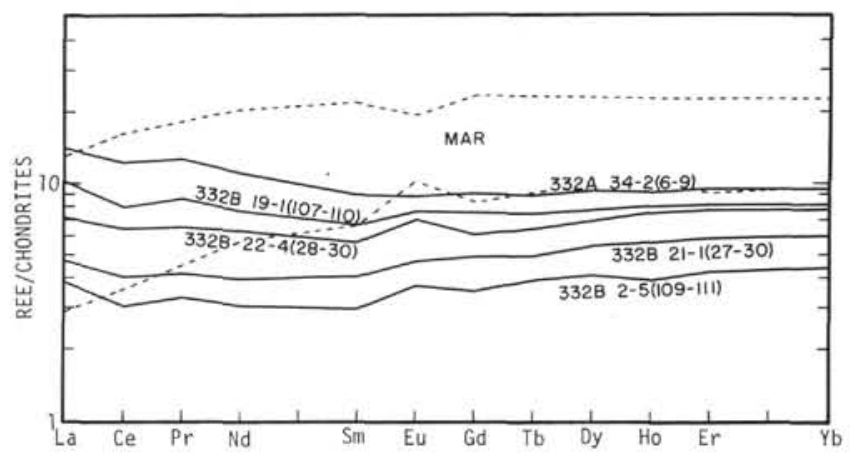

Figure 4. REE abundance patterns for Leg 37 Holes $332 \mathrm{~A}$ and $332 B$ samples. Range for Mid-Atlantic Ridge dredge samples from Kay et al. (1970).

not any of the samples can be related to the same primary liquid or liquids.

On major element and textural grounds, it appears that the sample that has experienced the least fractionation involving ferromagnesian phases is 332B-19$1,107-110 \mathrm{~cm}$, and it is logical to attempt to relate the other samples to it. From Figure 2 it is seen that 332B$19-1,107-110 \mathrm{~cm}$ is intermediate between the samples that fall along an olivine extraction (or addition) line. Addition of $15 \%-20 \%$ olivine (Foso) to this composition would produce the major element composition of 332B$21-1,27-30 \mathrm{~cm}$ (the olivine cumulate). However the trace element abundances of the two samples (Table 1) cannot be explained by such a model. Addition of $50 \%$ olivine to $332 \mathrm{~B}-19-1,107-110 \mathrm{~cm}$ is required to explain the concentrations in 332B-21-1, 27-30 cm. Consequently the latter must be derived from a different primary liquid generated by a higher degree of partial melting. Because olivine (Fo86-88) is the liquidus phase in Sample 332B-19-1, 107-110 cm and because its ratio $\mathrm{Mg} / \mathrm{Mg}+\mathrm{Fe}$ of 0.695 is consistent with slight olivine fractionation, its parent liquid was probably displaced along the olivine extraction line to slightly higher $\mathrm{MgO}$ concentrations from 332B-19-1, 107-110 cm in Figure 2.

Sample 332B-22-4, 18-20 cm which also falls along the olivine extraction line of Figure 2 is so extensively fractionated $\left(\mathrm{Mg} /\left(\mathrm{Mg}+\mathrm{Fe}^{2+}\right)=0.62\right)$ that it cannot be related to $332 \mathrm{~B}-19-1,107-110 \mathrm{~cm}$ solely through olivine fractionation. Removal of $5 \%$ olivine from 332B-19-1, 107-110 cm results in the $\mathrm{MgO}$ concentration of 332B-22-4, 18-20 cm, but does not produce the necessary decrease in $\mathrm{Mg} /\left(\mathrm{Mg}+\mathrm{Fe}^{2+}\right)$ nor does it give the required $\mathrm{Al}_{2} \mathrm{O}_{3}$ and $\mathrm{CaO}$ concentrations. The observed high values of $\mathrm{CaO}$ and $\mathrm{Al}_{2} \mathrm{O}_{3}$ in Sample $332 \mathrm{~B}-22-4,18-20 \mathrm{~cm}$ can be accounted for by $25 \%$ plagioclase accumulation, which is consistent with the observed positive Eu anomaly (Figure 4). However, the trace element characteristics of the two samples are such that the two cannot be related to each other through crystal fractionation processes. Consequently, a separate primary liquid must be invoked for 332B-22$4,18-20 \mathrm{~cm}$. Furthermore, again on both major and trace element grounds the two samples cannot be related to each other through different degrees of partial melting of the same source region. 
To relate Sample 332A-34-2, 6-9 cm to Sample 332B$19-1,107-110 \mathrm{~cm}$ requires approximately $10 \%$ olivine (Fo90) extraction and $<5 \%$ plagioclase cumulation. Both are consistent with the petrography of Sample $332 \mathrm{~A}-34-2,6-9 \mathrm{~cm}$. Higher percentage of olivine and plagioclase fractionation would be inconsistent with the major element relationships. On the other hand, the trace element abundances, if related solely through crystal fractionation, require concentration increases of from $60 \%$ to $70 \%$ in $332 \mathrm{~A}-34-2,6-9 \mathrm{~cm}$ liquids. Consequently, we conclude that the liquids cannot be related to a common parental liquid. However, the trace elements are consistent with the two being related to liquids derived from the same source region through different degrees of partial melting.

The plagioclase cumulate $332 \mathrm{~B}-25,109-111 \mathrm{~cm}$ is apparently unfractionated with respect to ferromagnesian phases, but contains $30 \%$ cumulate plagioclase. The major element characteristics of this sample are generally consistent with it being derived from 332B-19$1,107-110 \mathrm{~cm}$ through the accumulation of $30 \%-35 \%$ plagioclase (An85). However, the trace element relationships require a dilution factor of from 2.3 to 2.6 or the addition of $50 \%-60 \%$ plagioclase. Consequently, we suggest that the parental liquid to 332B-2-5, 109-111 $\mathrm{cm}$ may be related to $332 \mathrm{~B}-19-1,107-110 \mathrm{~cm}$ through different degrees of partial melting of a relatively homogeneous source region.

In summary, the major and trace element chemistry of the five samples is not consistent with their being derived from the same parental liquid through nearsurface crystal fractionation. However, with the exception of 332B-22-4, 18-20 cm, both the trace and major element characteristics are consistent with derivation from different parental liquids which were in turn derived by different degrees of partial melting of a chemically and mineralogically homogeneous source in this region.

The similar behavior of all of the incompatible elements studied suggests that these elements are present mainly in accessory phases in the upper mantle and are strongly partitioned into the early liquids during partial melting. Their abundance levels in the derivative liquids ther reflect the degree of partial melting of the source.

Assuming that Sample 332B-19-1, 107-110 cm is the most primitive sample of the five studied, and that it was derived by $\sim 20 \%$ partial melting, it is possible to estimate the relative degrees of partial melting of the source necessary to produce the trace element characteristics of the parental liquids of the other samples. Furthermore, an estimate can be made of the incompatible trace element abundances in the source.

From 332B-19-1, 107-110 cm, which contains $\sim 8$ times chondritic REE's, it appears that the source region contained $\sim 2$ times chondritic abundances. Sample 332B-2-5, 109-111 cm, corrected for 30\% cumulate plagioclase and assuming a similar degree of partial melting, leads to a source region having about chondritic REE abundances. If the source regions are characterized by 1-2 times chondritic REE, then, when corrected for fractionating phases, the following degrees of partial melting are required to produce the measured REE concentration in the other samples. 332 A-34-2, 6-9 cm, <5\% p.m.; 332B-21-1, 27-30 cm, 8$10 \%$ p.m.

Sample 332B-22-4, 28-30 cm has major and trace element characteristics incompatible with its parental liquid being derived from the same chemical source as the other four samples.

We conclude that the REE abundance patterns reflect the patterns in the source regions and that these sources are not depleted in La relative to $\mathrm{Sm}$ and $\mathrm{Yb}$. Apparently these sources have not experienced a previous melting event as appears to be the case for the source regions of the majority of MORB's. The patterns are consistent with the retention of clinopyroxene in the source. The unfractionated REE patterns indicate no differences in the source region phase assemblages for phases that would fractionate the rare earths (e.g., clinopyroxene or garnet).

\section{ACKNOWLEDGMENTS}

We wish to acknowledge the technical assistance of $\mathrm{P}$. Muir, W. Nance, and N. Ware. A.E.B. wishes to acknowledge financial support from A.N.U. and National Science Foundation Grants DES 74-22511 (Submarine Geology and Geophysics) and FO 43497 (Office of International Programs).

Specimens from Leg 37 were provided by the National Science Foundation. The assistance of W.G. Melson in making these samples available to us is gratefully acknowledged.

\section{REFERENCES}

Arth, J.G. and Hanson, G.N., 1975. Geochemistry and origin of the early Precambrian crust of northeastern Minnesota: Geochim. Cosmochim. Acta, v. 39, p. 325-362.

Bass, M.N., Moberly, R., Rhodes, J.M., Shih, C., and Church, S.E., 1973. Volcanic rocks cored in the Central Pacific, Leg 17, Deep Sea Drilling Project: EOS, v. 54, p. $991-995$.

Bence, A. E., Papike, J. J., and Ayuso, R. A., 1975. Petrology of submarine basalts from the central Caribbean-DSDP Leg 15: J. Geophys. Res., v. 80, p. 4775-4804.

Brunfelt, A.E. and Heier, K.S., 1971. Determination of 40 elements in Apollo 12 samples by neutron activation analysis: Apollo Second Lunar Sci. Conf. Proc., v. 2, p. 1281-1290.

Coleman, R.G., Tatsumoto, M., Goles, D.G., Hedge, C.E., and Mays, R.E., 1973. Red Sea Basalts: EOS, v. 54, p. 1001-1002.

Frey, F.A., Bryan, W.B., and Thompson, G., 1974. Atlantic ocean floor: Geochemistry and petrology of basalts from Legs 2 and 3 of the Deep Sea Drilling Project: J. Geophys. Res., v. 79, p. 5507-5527.

Gast, P.W., Hubbard, N.J., and Wiesmann, H., 1970. Chemical composition and petrogenesis of basalts from Tranquility Base: Apollo Second Lunar Sci. Conf. Proc., v. 2 , p. $1143-1163$.

Goles, G.G., 1971. Analyses of Apollo 12 specimens: compositional variations, differentiation processes and lunar soil mixing models. Apollo Second Lunar Sci. Conf. Proc., v. 2, p. 1063-1081.

Green, D.H., Edgar, A.D., Beasley, P., Kiss, E., and Ware, N.G., 1974. Upper mantle source for some hawaiites, mugearites, and benmoreites: Contrib. Mineral. Petrol., v. 48, p. $33-43$. 
Green, T.H., Green, D.H., and Ringwood, A.E., 1967. The origin of high alumina basalts and their relationships to quartz tholeiites and alkali basalts: Earth Planet. Sci. Lett., v. 2 , p. $41-51$.

Haskin, L.A., 1970. Rare earths and other trace elements in Apollo 11 lunar samples: Apollo Second Lunar Sci. Conf. Proc., v. 2, p. 1213-1231.

Hekinian, R., 1974. Petrology of the Ninety East Ridge (Indian Ocean) compared to other aseismic ridges: Contrib. Mineral. Petrol., v. 43, p. 125-147.

Kay, R., Hubbard, N., and Gast, P.W., 1970. Chemical characteristics and origin of oceanic ridge volcanic rocks: J. Geophys. Res., v. 75, p. 1585-1613.

Kempe, D.R.C., 1973. Basalts from the Southern Indian Ocean: DSDP Leg 26: EOS, v. 54, p. 1008-1011.

Nicholls, I., 1974. A direct fusion method preparing silicate rock glasses for energy-dispersive electron microprobe analysis: Chem. Geol., v. 14, p. 141-157.

Philpotts, J.A. and Schnetzler, C.C., 1970. Apollo II lunar samples: $\mathrm{K}, \mathrm{Rb}, \mathrm{Sr}, \mathrm{Ba}$ and rare-earth concentrations in some rocks and separated phases: Apollo Second Lunar Sci. Conf. Proc., v. 2, p. 1471-1486.
Ridley, W.I., Rhodes, J.M., Reid, A.M., Jakes, P., Shih, C., and Bass, M.N., 1974. Basalts from Leg 5 of the Deep-Sea Drilling Project: J. Petrol., v. 15, p. 140-159.

Robinson, P.T. and Whitford, D.W., 1974. Basalts from the eastern Indian Ocean, DSDP Leg 27. In Heirtzler, J., Veevers, J., et al., Initial Reports (U.S. Government Printing Office, Washington D.C.), p. 551-559.

Schilling, J-G., 1973. Iceland mantle plume: Geochemical evidence along Reykjanes ridge: Nature, v. 242, p. $565-$ 571.

Schilling, J-G. and Winchester, J.W., 1969. Rare earth contribution to the origin of Hawaiian lavas: Contr. Mineral. Petrol., v. 23, p. 27-37.

Taylor, S.R., 1965. Geochemical analysis by spark source mass spectrometry: Geochim. Cosmochim. Acta, v. 29, p. $1243-1261$.

1971. Geochemical application of spark source mass spectrometry II photoplate data processing: Geochim. Cosmochim. Acta, v. 35, p. 1187-1196. 